\title{
Priority regions for research on dryland cereals and legumes
}

\section{[version 1; peer review: 2 approved]}

\section{Glenn Hyman1, Elizabeth Barona², Chandrashekhar Biradar³, Edward Guevara1, John Dixon ${ }^{4}$, Steve Beebe ${ }^{1}$, Silvia Elena Castano ${ }^{1}$, Tunrayo Alabi5, Murali Krishna Gumma6 , Shoba Sivasankar6, Ovidio Rivera1, Herlin Espinosa", Jorge Cardona ${ }^{1}$}

\footnotetext{
${ }^{1}$ International Center for Tropical Agriculture (CIAT), Cali, Colombia

2Independent Researcher, Miami, USA

${ }^{3}$ International Center for Agricultural Research in the Dry Areas (ICARDA), Beirut, Lebanon

${ }^{4}$ Australian Centre for International Agricultural Research, Canberra, Australia

5International Institute of Tropical Agriculture (IITA), Ibadan, Nigeria

${ }^{6}$ International Crops Research Institute for the Semi-Arid Tropics (ICRISAT), Patancheru, India
}

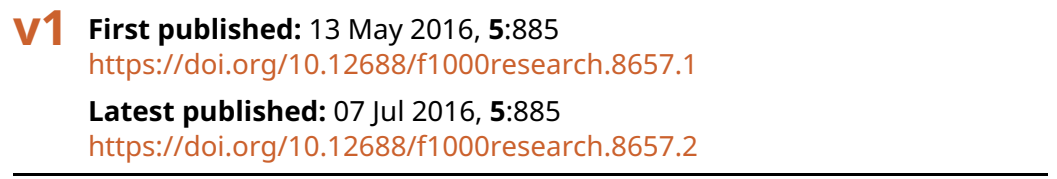

\section{Abstract}

Dryland cereals and legumes are important crops in farming systems across the world. Yet they are frequently neglected among the priorities for international agricultural research and development, often due to lack of information on their magnitude and extent. Given what we know about the global distribution of dryland cereals and legumes, what regions should be high priority for research and development to improve livelihoods and food security? This research evaluated the geographic dimensions of these crops and the farming systems where they are found worldwide. The study employed geographic information science and data to assess the key farming systems and regions for these crops. Dryland cereal and legume crops should be given high priority in 18 farming systems worldwide, where their cultivated area comprises more than 160 million ha. These regions include the dryer areas of South Asia, West and East Africa, the Middle East and North Africa, Central America and other parts of Asia. These regions are prone to drought and heat stress, have limiting soil constraints, make up half of the global population and account for 60 percent of the global poor and malnourished. The dryland cereal and legume crops and farming systems merit more research and development attention to improve productivity and address development problems. This project developed an open access dataset and information resource that provides the basis for future analysis of the geographic dimensions of dryland cereals and legumes.

\section{Open Peer Review}

Approval Status

1 2

version 2

(revision)

07 Jul 2016

version 1

13 May 2016

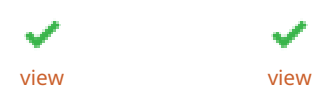

1. Jeffrey D. Ehlers, Bill and Melinda Gates Foundation, Seattle, USA

2. Liangzhi You, International Food Policy Research Institute, Washington, USA

Any reports and responses or comments on the article can be found at the end of the article. 
Keywords

Grain legumes, dryland cereals , farming systems , priority setting , geographic priorities

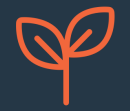

This article is included in the Agriculture, Food

and Nutrition gateway.

Corresponding author: Glenn Hyman (g.hyman@cgiar.org)

Competing interests: This research was commissioned by the CGIAR, a consortium of international research centers where all but one of the authors is employed. Future funding of research programs on dryland cereals and legumes could be influenced by the results and information found in this paper, which could impact on funds received by individual CGIAR centers. The authors declare no direct competing interest. All organizations for which the authors are employed are nonprofit organizations dedicated to developing global public goods.

Grant information: This research was commissioned by the CGIAR Research Programs on Grain Legumes (http://grainlegumes.cgiar.org/) and on Dryland Cereals (http://drylandcereals.cgiar.org/). The CGIAR Fund (http://www.cgiar.org/whowe-are/cgiar-fund/) provided financial support for the study to the authors from four Consultative Group on International Agricultural Research (CGIAR) centers - CIAT, ICARDA, ICRISAT and IITA.

The funders had no role in study design, data collection and analysis, decision to publish, or preparation of the manuscript.

Copyright: @ 2016 Hyman G et al. This is an open access article distributed under the terms of the Creative Commons Attribution License, which permits unrestricted use, distribution, and reproduction in any medium, provided the original work is properly cited.

How to cite this article: Hyman G, Barona E, Biradar C et al. Priority regions for research on dryland cereals and legumes [version 1; peer review: 2 approved] F1000Research 2016, 5:885 https://doi.org/10.12688/f1000research.8657.1

First published: 13 May 2016, 5:885 https://doi.org/10.12688/f1000research.8657.1 


\section{Introduction}

International agricultural research and development programs usually consider the geographic dimensions of crop improvement and farming systems in their efforts to prioritize activities (Hyman et al., 2013). Where is the crop grown globally and what are the key obstacles to crop production? Does the research apply to places where benefits can reach a large number of people? How can resources be allocated to achieve efficiencies? But answering these questions requires integration of socioeconomic and biophysical data and the integration of wide-ranging data and information resources. Often data exists for national jurisdictions, but it needs to be evaluated by agroecology or farming system. The task is even more difficult for crops such as dryland cereals and grain legumes because - when compared to the major staple crops - these crops are often embedded in complex crop-livestock systems and less information is available. The Dryland Cereals and Legumes Agri-Food System research program of the CGIAR (the program is hereafter referred to as DCL) requested an analysis of the principal commodities of their proposed program and the farming systems in which they are found. The 12 priority crops of these dryland systems are chickpea, common bean, cowpea, faba bean, groundnut, lentil, pigeon pea, soybean, barley, pearl millet, small millet and sorghum (DCL, 2015). The research presented in this paper shows the development of spatial and statistical data intended to support geographic priority setting for the global DCL research program. In order to develop the analysis, this research builds on a global classification of farming systems, on maps of the spatial distribution of all 12 DCL crop commodities, on socioeconomic data on population, poverty, malnutrition, on market access, and on soil and climatic data. The analysis identifies where these crops occur in the context of constraints and opportunities for their development. How can DCL technologies be geographically targeted for achieving the objective of reducing poverty and malnutrition in dryland systems? The present analysis is based on a diverse array of geographic information, and includes new assessments of poverty, drought, heat and other information related to crop improvement and management. In this way, the study examines the spatial extents of key constraints to DCL crop production, using the most recent spatial data available. The analysis and resulting database provides the first global farming systems information resource for specifically evaluating priorities for DCL crop improvement and management. Tabular data from this analysis is open access and has been published in a data repository (Barona et al., 2016a). The geospatial data used this study can be accessed through a new online digital atlas for dryland cereals and grain legumes (see http://www.eatlasdcl.cgiar.org/).

\section{Methodology}

This study builds on previous work (including Dixon et al., 2001 and Hyman et al., 2008), but with a focus on the 12 principal commodities and farming systems of DCL. The main framework for the study is John Dixon's farming systems framework, a global delineation and resulting map of the major farming systems of the developing world (Dixon et al., 2001). Dixon's schema is built on 15 biophysical and socioeconomic spatial data layers available in the year 2000 and consultations with hundreds of regional and global agricultural experts using a modified Delhi technique. In a participatory process, 72 global farming systems in six developing regions were geographically delineated and their characteristics described. The present study uses a subset of 63 of those farming systems together with new spatial data on biophysical and socioeconomic conditions to characterize the extents of DCL commodities. Using spatial overlay, biophysical and socioeconomic information are organized according to the 63 Dixon farming systems.

A key advantage of this research was that instead of analyzing crop information by country, subnational estimates of crop distribution are generated based on pixel level data (Hyman et al., 2008). Then, using spatial overlay, we organize that data by country (250 in total), by farming system ( 63 types) and by combinations of countries and farming systems (544 combinations). Other data is also organized according to farming system and country - including information on drought, temperature dynamics with climate change, soil conditions, population and poverty. Readers should consult our previous publication and available data for further details on the data and methodology (Barona et al., 2016a and Barona et al., 2016b; Hyman et al., 2008; Hyman et al., 2015).

\section{Data sources}

Spatial information on biophysical and socioeconomic conditions was acquired, with the objective of obtaining the most recent and spatially detailed information related to dryland cereals and legume and the agricultural systems where they are found. The present study upgrades our previous work because we are using data that was not available before, especially the 2005 spatial distribution of crop area, production and yield (You \& Wood, 2006; You et al., 2014a; You et al., 2014b). The previous study used crop distribution data from the year 2000, while the work we describe here uses 2005 crop distribution data. Our previous dataset only included 7 DCL commodities, in contrast to all 12 of the DCL commodities used here. These new data also benefited from improved spatial resolution and modeling procedures. This study used the most recent available data on global livestock and human population. The source of the year 2010 human population data was the gridded population of the world project (CIESIN, 2014). Livestock population was taken from the Gridded Livestock of the World (GLW) database at $5 \mathrm{~km}$ spatial resolution, with the year 2005 as the reference year (Robinson et al., 2014).

Several datasets gave us information on abiotic constraints to crop production that are important for the DCL commodities. The dataset includes indicators of drought based on maps of drought probability and the "failed seasons" concept. By simulating rainfall for defined crop water requirements, the probability of a growing season failing to produce a successful harvest indicates drought risk for every pixel across the world (Hyman et al., 2008; Jones \& Thornton, 2000; Jones et al., 2002). The drought probability is multiplied by total crop area to derive the potential drought impact index (PDII). Furthermore, the needed heat tolerance for DCL crops was indicated by estimates of expected temperature change between the current temperature and 2050 temperatures (Hijmans et al., 2005, Ramirez \& Jarvis, 2008). These predicted changes are based on global circulation models (GCM) under the A1B scenario, assuming rapid economic growth with emissions peaking around 2050. The study used maps of soil constraints based on the fertility capability classification (Sanchez et al., 2003). These constraints included soil acidity, length of the dry season, waterlogging, low nutrient 
availability and salinity - all constraints identified by DCL crop experts as important obstacles to overcome (DCL, 2015). Finally, the length of the growing period indicates seasonal constraints on crops that may be relevant for the breeding objectives of DCL crops (Fischer, 2009).

Detailed geographic information on population is not usually available until at least five years after the dates of censuses and surveys. Our analysis includes estimates of the total population for the year 2010, as well as total, rural and urban population for 2005 (CIESIN et al., 2005; CIESIN, 2014). We included 2005 population data in our analysis because the CIESIN (2014) population dataset does not yet include urban and rural data for 2010. The analysis draws on estimates of the number of people living on less than $\$ 1$ and $\$ 2$ per day for $10 \mathrm{~km}$ pixel areas, based on estimates derived from combined poverty maps and survey data for the entire world, with a base year of 2005. This global poverty data set is not available in the public domain, but interested users of poverty data should consult the HarvestChoice website to learn more about this and other poverty mapping initiatives (Stanley Wood, personal communication). Nutrition indicators include the absolute number and proportional numbers of children under five years old that are two standard deviations below the median of weight for age (underweight) and height for age (stunting), according to international standards (CIESIN, 2005; FAO, 2007).

\section{Spatial analysis}

Spatial overlay was used to organize the data into spatial units according to farming system and combinations of farming systems and country. All spatial data was converted to the Robinson equal area projection at $10 \mathrm{~km}$ spatial resolution before processing commenced. We used the zonal statistics tools in ArcInfo Workstation 10.0 and ArcGIS Desktop 10.1 software. The analysis digitally overlays Dixon's farming systems map and a global map of country boundaries on the socioeconomic and biophysical map data described above. The result of the overlay procedure is a set of database files (dBase format) organized by farming system region and combination of farming system region and country. The database files were then converted to 40 spreadsheet files in Excel format (Barona et al., 2016b). An additional analysis was made of the pixels where more than one DCL crop occurred within the pixel. For each crop, if the area value in the pixel was higher than the mean for all pixels of that crop, it was considered to be of a sufficient density to map these crop combinations. By selecting only those pixels above the mean, we excluded those areas that may have a small concentration of the crop. The creation of the tables was facilitated using scripts written in Arc Macro Language (AML) to facilitate updates as more recent or better data becomes available (scripts and data available from Barona et al., 2016b).

\section{Determining priority regions}

The study used a mix of criteria for determining priority regions for research and development in DCL farming systems. A modified "natural breaks" approach was our primary consideration in selecting priority farming system regions. Building on the determination of classes for choropleth mapping, the approach visually inspects the data to find where farming system regions group together according to their levels of DCL crop area (Smith, 1986). We also considered whether a single crop dominated a farming system region in areas with large farms and well-developed agroindustries. Some farming systems that have relatively small DCL crop areas could be included if they were similar to regions that have large areas, something that often occurs with farming systems in different regions of the world.

Another criteria was whether these farming systems overlapped with DCL program target countries, as established in the DCL preproposal (DCL, 2015). A key criteria for program target countries is that they fall within dryland regions, defined as areas with an aridity index between 0.03 and 0.65 (Zomer et al., 2008). A dryland regions map and a description of how it was made can be accessed on the online DCL Atlas. Beyond this consideration, the DCL program's target country analysis considered crop area and production, people living in poverty, childhood malnutrition, land degradation and other considerations - all with national level data. The reference map in the online atlas contains the map of target countries of the DCL program.

The approach we describe above leaves open the possibility to select different criteria and to expand or contract the number of farming systems that would be targeted for a research and development program. The publication of replication data found in the online atlas and in the Dataverse repository enable future iterations of the analysis according to any adjustments that the program may want to make (Barona et al., 2016a).

\section{Results}

The DCL crops are concentrated in 18 farming systems where more than 160 million ha of these crops are cultivated, where more than $60 \%$ of the world's poor live and where the DCL commodity programs have selected target countries based on their fit with dryland systems (Figure 1; Table 1 \& Table 7; DCL, 2015; DESA, 2009). We selected these farming systems if the farming system had at least six million ha of combined DCL crops. However, we excluded three Latin American and Caribbean (LAC) farming systems that met this threshold because these systems were overly dominated by soybean production in regions with typically large farms. These excluded systems were temperate mixed (Pampas), cereal-livestock (Campos) and extensive mixed (Cerrados_Llanos).

Priority DCL farming systems were included from Latin America and the Middle East and North Africa (MENA) regions that did not meet the six million hectare threshold described above. The maizebeans farming system in Mesoamerica was added because it is very similar to maize mixed system in sub-Saharan Africa. The rainfed mixed and pastoral farming systems in the MENA region were added because they are similar to farming systems in sub-Saharan Africa (pastoral) and in South Asia (rainfed mixed). Two other farming systems - dry rainfed and highland mixed - are included on the basis of traditional importance in the dryland MENA region.

\section{Production, area and yield}

Three farming systems in South Asia - rainfed mixed, ricewheat and dry rainfed - make up about one third of the 162 million ha of DCL crops in the 18 priority farming systems (Table 1). The rainfed mixed system makes up 20\% of the DCL crop area in these priority farming systems, accounting for more than 30 million ha of DCL crops. A second important 


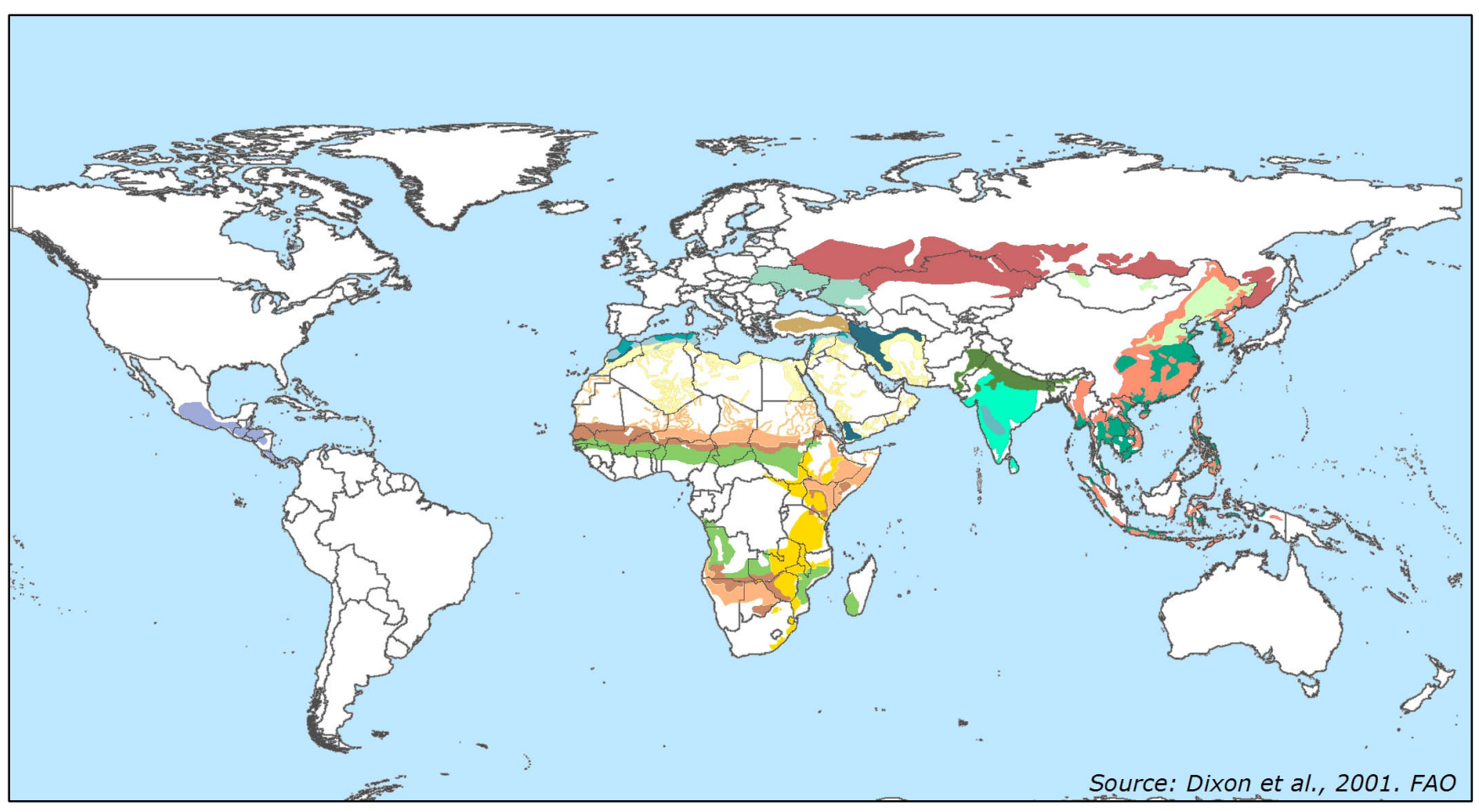

18 DCL Farming Systems

\begin{tabular}{|l}
\hline Lowland rice \\
\hline Agro-pastoral millet/sorghum \\
\hline Pastoral (SSA) \\
\hline Highland mixed \\
Rainfed mixed (MENA) \\
Rice-wheat
\end{tabular}

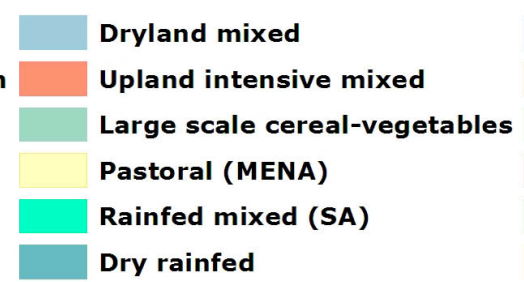

Dryland mixed

Upland intensive mixed Pastoral (MENA)

Rainfed mixed (SA)

Dry rainfed

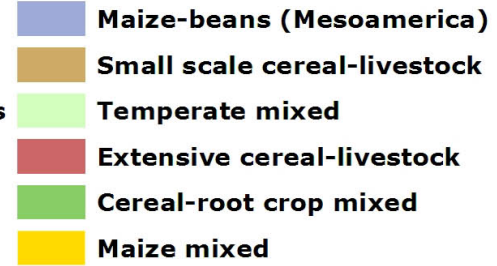

Maize-beans (Mesoamerica)

Temperate mixed

Extensive cereal-livestock

Maize mixed

Figure 1.18 priority dryland cereal and legume priority farming systems worldwide.

region is Sub-Saharan Africa, where the cereal-root crop mixed system accounts for 21.3 million ha, the agro-pastoral millet sorghum system accounts for 18.6 million ha, the pastoral system accounts for 10.8 million ha and the maize mixed system has 7.6 million ha. In Eastern Europe and Central Asia more than 15 million ha are cultivated, with barley figuring prominently. In East Asia over 22 million ha are cultivated, with groundnut and soybean as the predominant crops. The overall DCL crop area in the Middle East and North Africa is the lowest among the 18 priority regions suggested above.

In some cases DCL crops make up a large proportion of the total cultivated area in these farming systems, but their overall area may be relatively small when they are found in systems with large areas of maize, wheat and rice (Table 2). Three cereals (barley, pearl millet and sorghum) and two legumes (soybean and cowpea) play key roles in several farming systems where they make up more than $10 \%$ of all cultivated crop area within the system. The legumes are multi-purpose, contributing soil fertility, family nutrition, fodder and cash sales. Seven relatively cooler farming systems have more than 13 percent of their crop area in barley - four of which are in the Middle East and North Africa and three in Eastern Europe and Central Asia region. Pearl millet is an important component in the higher temperature pastoral, agro-pastoral millet-sorghum and cereal-root crop mixed farming systems, making up 35\%, 32\% and $11 \%$ of the total cultivated area respectively. In the pastoral and agro-pastoral millet-sorghum systems pearl millet is a major food crop, whereas in the somewhat higher rainfall cereal-root crop mixed system maize, sorghum and cassava are the major food crops. In three African systems and one South Asian system, sorghum makes up more than $20 \%$ of the total cultivated area, although being pushed back by drought tolerant maize. In five of these 18 farming systems groundnuts make up between five and eight percent of the total cultivated area. The remaining crops - bean, chickpea, lentil, small millet and pigeon pea - have a smaller overall agricultural footprint.

Yields vary across the 18 farming systems and by DCL commodity (Table 3). A very general pattern is that yields are lowest in sub-Saharan Africa. They are somewhat higher in South Asia and 
Table 1. DCL crop area in '000's of hectares in 18 priority farming systems worldwide.

\begin{tabular}{|c|c|c|c|c|c|c|c|c|c|c|c|c|c|c|}
\hline $\begin{array}{l}\text { FARMING } \\
\text { SYSTEMS }\end{array}$ & REGION & BARL & BEAN & CHKP & COWP & GRDN & LENT & PMIL & PSML & PPEA & SORG & SOYB & FABAB & TOTAL \\
\hline $\begin{array}{l}\text { Cereal-root } \\
\text { crop mixed }\end{array}$ & SSA & 26 & 573 & 32 & 2,983 & 2,949 & 1 & 4,649 & 128 & 78 & 9,594 & 295 & 19 & 21,328 \\
\hline Maize mixed & SSA & 81 & 2,175 & 107 & 387 & 977 & 7 & 655 & 432 & 431 & 1,976 & 309 & 70 & 7,607 \\
\hline $\begin{array}{l}\text { Agro-pastoral } \\
\text { millet/sorghum }\end{array}$ & SSA & 2 & 169 & 1 & 3,489 & 1,751 & 0 & 7,551 & 0 & 8 & 5,596 & 108 & 15 & 18,691 \\
\hline Pastoral & SSA & 65 & 77 & 21 & 2,070 & 725 & 7 & 4,798 & 9 & 0 & 2,955 & 14 & 66 & 10,808 \\
\hline Rice-wheat & SA & 461 & 1,575 & 1,966 & 0 & 277 & 977 & 4,012 & 144 & 543 & 966 & 362 & 0 & 11,283 \\
\hline Rainfed mixed & SA & 161 & 3,951 & 4,062 & 4 & 4,014 & 595 & 2,628 & 1,697 & 2,149 & 4,226 & 7,276 & 0 & 30,763 \\
\hline Dry rainfed & SA & 0 & 496 & 1,030 & 0 & 1,168 & 0 & 1,148 & 68 & 735 & 3,829 & 210 & 0 & 8,685 \\
\hline $\begin{array}{l}\text { Highland } \\
\text { mixed }\end{array}$ & MENA & 1,704 & 83 & 524 & 0 & 1 & 189 & 1 & 67 & 0 & 291 & 75 & 28 & 2,961 \\
\hline Rainfed mixed & MENA & 1,197 & 22 & 94 & 0 & 26 & 69 & 5 & 2 & 0 & 17 & 1 & 156 & 1,589 \\
\hline Dryland mixed & MENA & 3,486 & 6 & 126 & 0 & 7 & 125 & 0 & 11 & 0 & 10 & 7 & 62 & 3,841 \\
\hline Pastoral & MENA & 737 & 18 & 40 & 0 & 13 & 37 & 0 & 19 & 0 & 120 & 4 & 11 & 1,001 \\
\hline $\begin{array}{l}\text { Maize-beans } \\
\text { (Mesoamerica) }\end{array}$ & LAC & 277 & 783 & 30 & 0 & 23 & 8 & 0 & 0 & 1 & 597 & 15 & 17 & 1,750 \\
\hline $\begin{array}{l}\text { Large scale } \\
\text { cereal- } \\
\text { vegetable }\end{array}$ & EECA & 5,927 & 44 & 2 & 0 & 0 & 1 & 0 & 309 & 0 & 30 & 634 & 1 & 6,948 \\
\hline $\begin{array}{l}\text { Small scale } \\
\text { cereal- } \\
\text { livestock }\end{array}$ & EECA & 2,057 & 59 & 235 & 0 & 6 & 181 & 0 & 2 & 0 & 0 & 0 & 9 & 2,550 \\
\hline $\begin{array}{l}\text { Extensive } \\
\text { cereal- } \\
\text { livestock }\end{array}$ & EECA & 8,322 & 5 & 12 & 0 & 0 & 6 & 0 & 535 & 0 & 22 & 250 & 6 & 9,161 \\
\hline Lowland rice & EAP & 408 & 2,436 & 1 & 39 & 2,805 & 16 & 53 & 28 & 18 & 91 & 2,696 & 187 & 8,778 \\
\hline $\begin{array}{l}\text { Upland } \\
\text { intensive } \\
\text { mixed }\end{array}$ & EAP & 154 & 1,167 & 86 & 65 & 1,629 & 20 & 522 & 25 & 436 & 170 & 3,336 & 258 & 7,869 \\
\hline $\begin{array}{l}\text { Temperate } \\
\text { mixed }\end{array}$ & EAP & 75 & 259 & 1 & 0 & 1,202 & 16 & 209 & 3 & 0 & 264 & 4,178 & 333 & 6,539 \\
\hline TOTAL & & 25,141 & 13,899 & 8,371 & 9,039 & 17,576 & 2,257 & 26,233 & 3,477 & 4,399 & 30,754 & 19,770 & 1,236 & 162,152 \\
\hline
\end{tabular}

even more so in Eastern Europe and Central Asia. Finally they are highest in the East Asian countries. These differences are related to many different factors, including population density, access to agricultural services and markets, biotic and abiotic constraints, technology levels, management practices and others.

\section{Livestock and DCL farming systems}

Livestock is an important component of the DCL research program and all the farming systems where DCL crops are concentrated. The DCL crops are considered multi-purpose crops because they are used for many purposes including food, feed and fodder - as well as ecosystem services. Soybean and barley are perhaps the most important for livestock, with much of their production going towards animal fodder (Hartman et al., 2011; Newton et al., 2011). Sorghum and millet is also very important as feed and fodder in sub-Saharan Africa. Table 4 shows the estimated 2005 and 2000 cattle population in each of the DCL priority farming systems. The size of the cattle population generally follows the size of human population, the number of poor and the area of crops (Table 1, Table 4 and Table 7, respectively). Two farming systems stand out for their high population of cattle - rainfed mixed and rice-wheat, both in South Asia. However, high population and crop area in East Asia do not translate into the very high cattle populations seen in South Asia. For example, the three East Asia priority farming systems - lowland rice, upland intensive mixed and temperate mixed - have cattle populations in the middle of the range of the priority systems, although pig populations are larger. Other priority systems in the middle of the range include cerealroot crop mixed, agro-pastoral millet sorghum, pastoral, extensive cereal-livestock and maize mixed. While the small-scale cereal livestock system in Eastern Europe and Central Asia and the dry rainfed system in South Asia have relatively low cattle populations among the priority systems, livestock is clearly important in these systems. 


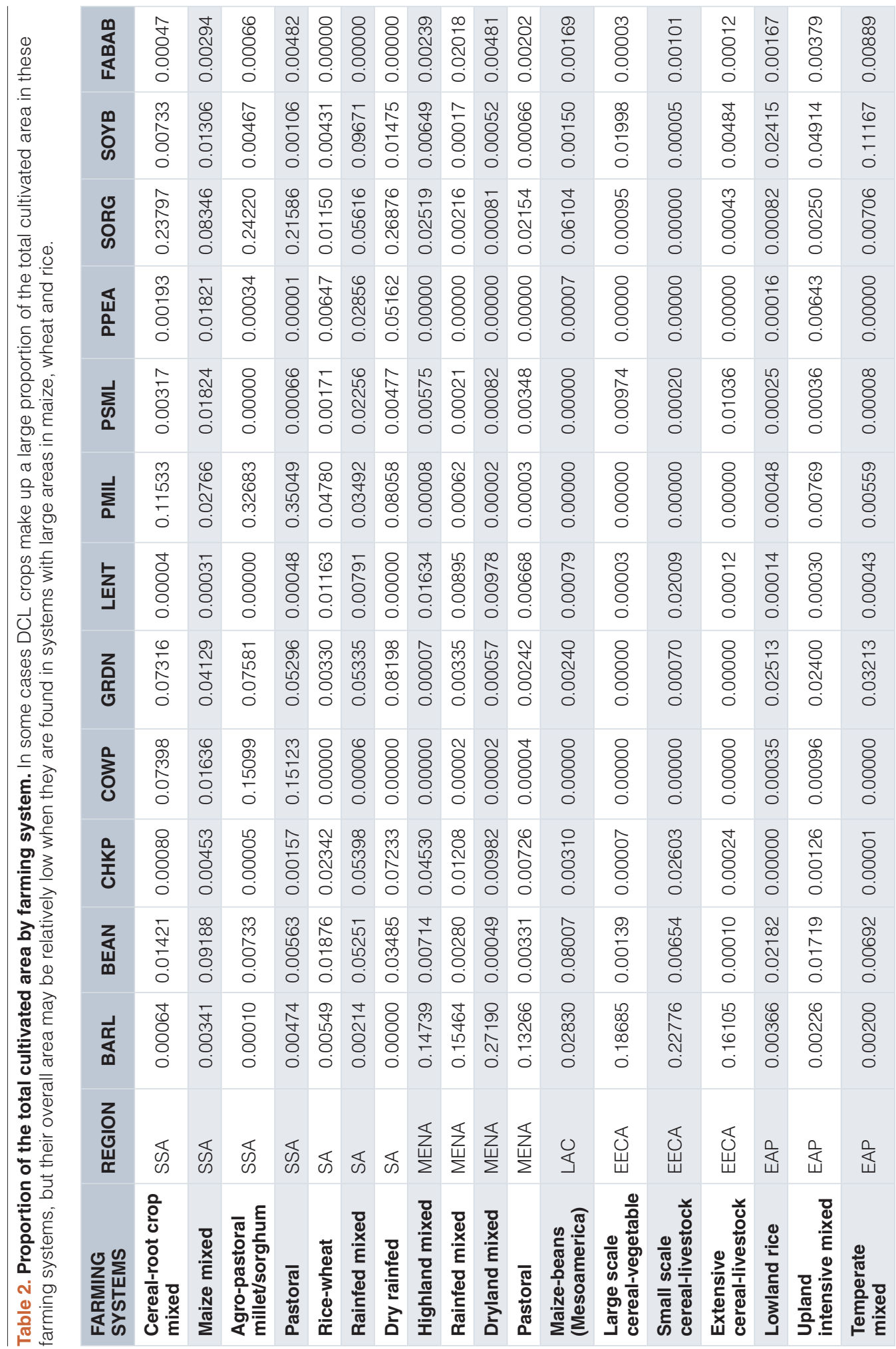




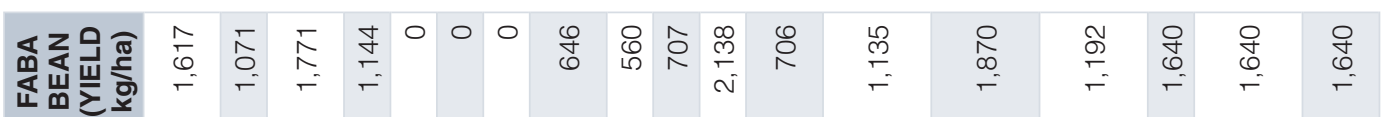

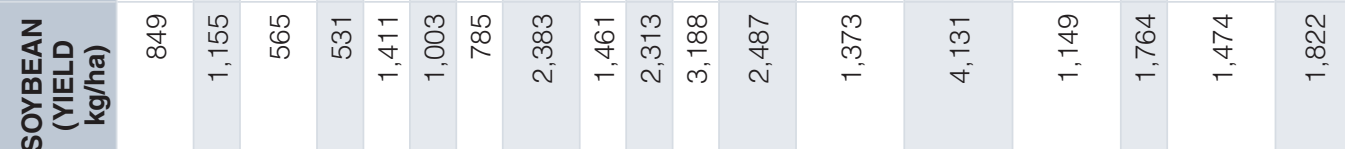

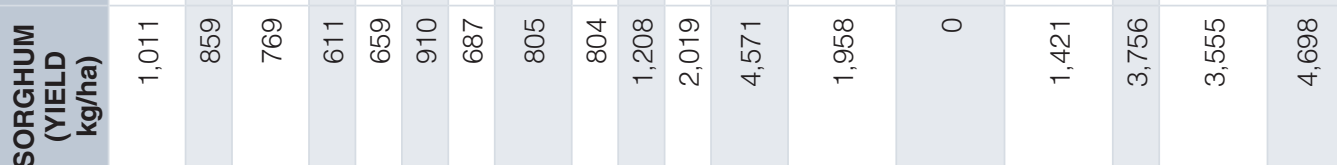

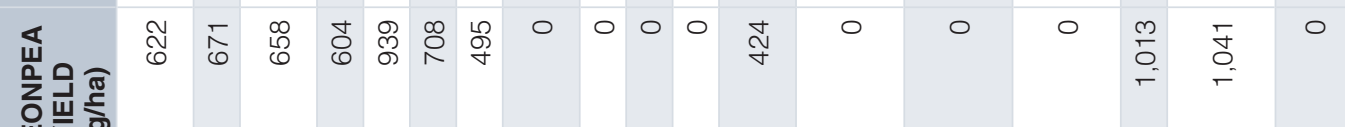
递文

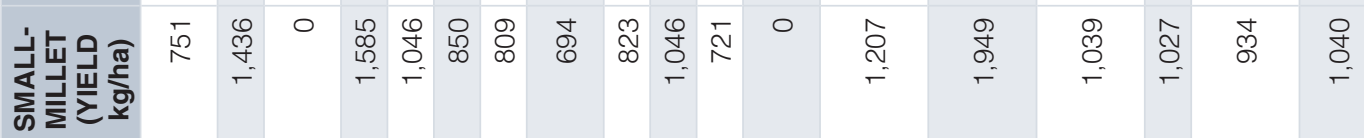

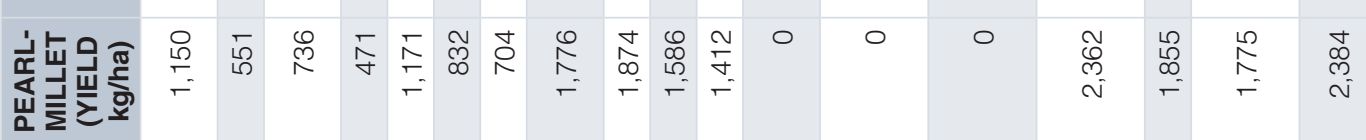

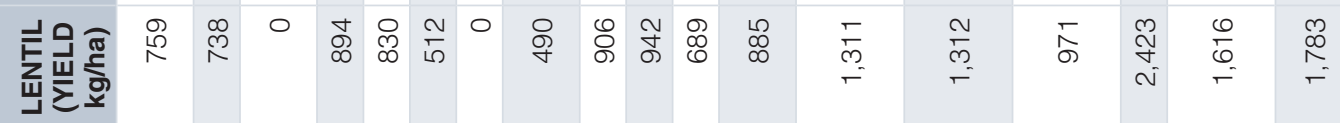
을호

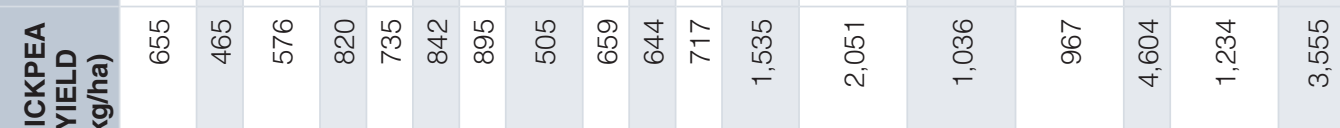
농로온

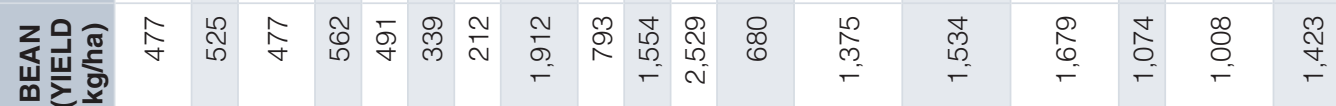

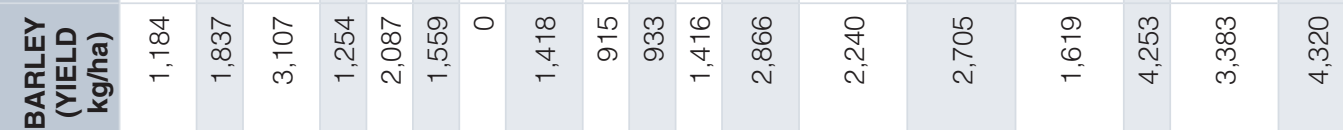

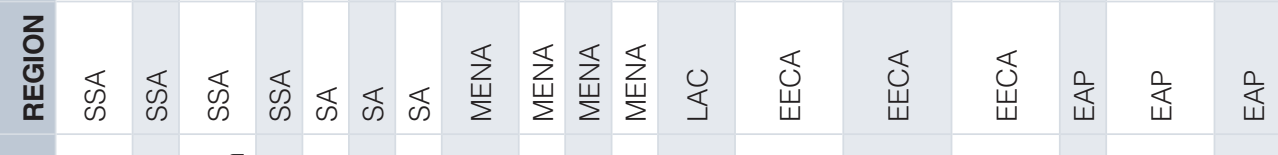

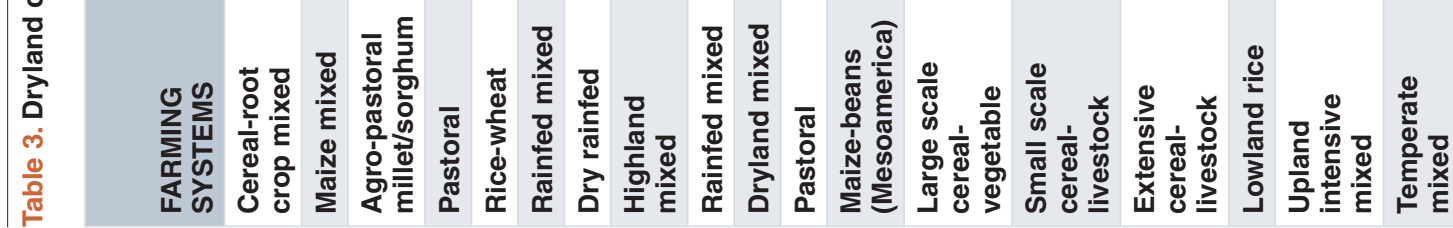


Table 4. Cattle population (head 2005 and 2010).

\begin{tabular}{|l|l|r|r|}
\hline FARMING SYSTEMS & REGION & $\begin{array}{c}\text { Cattle } \\
\text { Population }\end{array}$ & $\begin{array}{c}\text { Cattle } \\
\text { (head, 2005) }\end{array}$ \\
(head, 2010)
\end{tabular}

\section{Abiotic constraints}

The farming systems where dryland cereals and grain legumes are concentrated are particularly prone to drought and high temperatures (Table 5). Farming systems in areas with relatively low (and variable) annual precipitation are more susceptible to failed growing seasons, as shown in Figure 2. These dryland systems, especially those with less than $1000 \mathrm{~mm}$ of annual precipitation, tend to have a higher probability of drought or a failed season, when precipitation does not meet crop requirements. Areas that have high probabilities of being affected by drought as shown by the potential drought impact index (PDII) include the rainfed mixed system in South Asia and the agro-pastoral millet sorghum and pastoral systems in sub-Saharan Africa (Table 5). The rice-wheat system in South Asia also has a high PDII, where drought may particularly affect pearl millet and chickpea. Other systems that are particularly prone to drought include cereal-root crop mixed and maize mixed in sub-Saharan Africa and dry rainfed in South Asia.

The DCL crops are also expected to be constrained by the rising temperatures that come with climate change. There is a general tendency of the drier farming systems having higher expected temperature changes between now and 2050 (Figure 3). Average temperature changes are expected to be between 2.4 and $3.4^{\circ} \mathrm{C}$. The DCL priority farming systems in Eastern Europe and Central Asia could be particularly hard hit, with expected temperature rises of $3.3^{\circ} \mathrm{C}$ for extensive cereal livestock and $2.8^{\circ} \mathrm{C}$ for both large-scale cereal vegetable and small-scale cereal livestock. The estimated temperature change by 2050 in the temperate mixed system in East Asia is $2.9^{\circ} \mathrm{C}$. For the rice-wheat system in South Asia and the agro-pastoral millet sorghum system in sub-Saharan Africa the expected change is $2.8^{\circ} \mathrm{C}$, important expected changes because of their large area of DCL crop cultivation. The ricewheat system has more than 11.2 million ha of DCL crops, while the agro-pastoral millet sorghum system has more than 18.6 million ha.

The soils of DCL priority farming systems present a number of abiotic constraints to DCL crop production. Table 6 shows some of the principal constraints identified by the DCL commodity programs as they affect priority farming systems (DCL, 2015). The proportional area of farming systems with acid soil ranges from $9 \%$ in the small-scale cereal livestock system to $39 \%$ in the rainfed mixed system. The cereal-root crop mixed system is another one with a very large proportion - 37 percent - of its area exhibiting acid soils. Another system with a large area of acid soils is the maize mixed system in sub-Saharan Africa, with 27 percent of its area under this constraint. Lowland rice and upland intensive mixed in East Asia have nearly a quarter of their areas with acid soil constraints. These latter two systems also suffer from large areas with soils of low nutrient availability, with over one third of the area under this condition. Low nutrient availability is also an important constraint in the cereal-root crop mixed, maize beans and rainfed mixed systems, with proportional areas of 19, 14 and 10 percent of their total areas under this constraint, respectively. Salinity constraints are less problematic, with 13 of the 15 priority farming systems having less than $6 \%$ of their areas with this condition. The exceptions for soils with salinity constraints are the rice-wheat system in South Asia with 23 percent and the temperate mixed system in East Asia with 18 percent of their areas subject to salinity constraints. A group of farming systems has between 20 and 40 percent of their areas on soils with low moisture holding capacity - an important constraint in dryland systems due to the need for soils to store water for as long as possible. These systems include the agro-pastoral millet sorghum (38\%), pastoral (30\%) and cereal-root crop mixed (22\%) farming systems in sub-Saharan Africa.

\section{Socioeconomics}

The key DCL farming system regions are home to about half of the global population, including a massive number of people living in poverty (Table 7). About 3.5 billion people live in these areas, 2.3 billion of them living in rural areas and 1.3 billion in towns and cities. The highest populations are in South Asia and East Asia. The lowland rice and upland intensive mixed systems in East Asia are two of the largest systems in terms of population, with roughly 851 and 501 million people in each respective system. Important South Asian farming systems include large numbers of urban and rural people - with over 400 million people in the rainfed mixed system and over 600 million people in the rice-wheat system. The remaining 14 DCL priority farming systems have a total of more than 960 million people. 
Table 5. The farming systems where dryland cereals and grain legumes are concentrated are particularly prone to high temperatures and drought.

\begin{tabular}{|c|c|c|c|c|}
\hline FARMING SYSTEMS & REGION & $\begin{array}{l}\text { DLC Crop } \\
\text { Area (ha) }\end{array}$ & $\begin{array}{l}\text { Potential Drought } \\
\text { Impact Index }\end{array}$ & $\begin{array}{l}\text { Temperature } \\
\text { Change } 2050\end{array}$ \\
\hline Cereal-root crop mixed & SSA & $21,327,541$ & $2,971,040$ & 2.48 \\
\hline Maize mixed & SSA & $7,606,508$ & $1,592,730$ & 2.47 \\
\hline $\begin{array}{l}\text { Agro-pastoral millet/ } \\
\text { sorghum }\end{array}$ & SSA & $18,691,342$ & $7,644,810$ & 2.77 \\
\hline Pastoral & SSA & $10,808,337$ & $7,409,830$ & 2.73 \\
\hline Rice-wheat & SA & $11,282,838$ & $4,431,820$ & 2.83 \\
\hline Rainfed mixed & SA & $30,763,078$ & $7,556,180$ & 2.48 \\
\hline Dry rainfed & SA & $8,685,308$ & $2,868,150$ & 2.36 \\
\hline Highland mixed & MENA & $2,961,344$ & 98,050 & 3.01 \\
\hline Rainfed mixed & MENA & $1,588,829$ & 123,471 & 2.64 \\
\hline Dryland mixed & MENA & $3,840,974$ & 104,013 & 2.79 \\
\hline Pastoral & MENA & $1,000,516$ & 10,668 & 2.93 \\
\hline $\begin{array}{l}\text { Maize-beans } \\
\text { (Mesoamerica) }\end{array}$ & LAC & $1,749,799$ & 398,401 & 2.36 \\
\hline $\begin{array}{l}\text { Large scale cereal- } \\
\text { vegetable }\end{array}$ & EECA & $6,947,991$ & 86,502 & 2.82 \\
\hline $\begin{array}{l}\text { Small scale cereal- } \\
\text { livestock }\end{array}$ & EECA & $2,550,258$ & 1,849 & 2.82 \\
\hline $\begin{array}{l}\text { Extensive cereal- } \\
\text { livestock }\end{array}$ & EECA & $9,160,822$ & 17,198 & 3.31 \\
\hline Lowland rice & EAP & $8,778,265$ & 982,407 & 2.25 \\
\hline $\begin{array}{l}\text { Upland intensive } \\
\text { mixed }\end{array}$ & EAP & $7,868,661$ & $1,065,610$ & 2.42 \\
\hline Temperate mixed & EAP & $6,539,133$ & $1,088,910$ & 2.91 \\
\hline
\end{tabular}

The DCL priority farming systems are home to a large proportion of the world's poor (Table 7). According to year 2005 childhood stunting and $\$ 1$ and $\$ 2$ a day poverty indicators, about $60 \%$ of the world's poor live within these 18 systems (Table 7; FAO, 2007; Stanley Wood, personal communication). This large proportion is due to the importance of these systems in high-population countries like China and India, as well as farming systems spanning West and East Africa. Of the 63 global farming systems, the DCL priority systems include eight of the top 10 systems in terms of numbers of poor people. These eight DCL systems are rice-wheat and rainfed mixed in South Asia, lowland rice, upland intensive mixed and temperate mixed in East Asia and cereal-root crop mixed, maize mixed and agro-pastoral millet sorghum in sub-Saharan Africa.

Using the population of stunted children as a nutrition and poverty indicator, more than 60 percent of the 2005 global population of stunted children live within the DCL priority farming systems (Table 7; de Onis et al., 2012; FAO, 2007). Much of this poverty is concentrated in South Asia, East Asia and sub-Saharan Africa, regions with historically high rates of malnutrition. According to the stunting indicator, two farming systems stand out, both in
South Asia. The rice-wheat and rainfed mixed systems have 28 and 24 million stunted children, respectively, with malnutrition levels exemplifying the high population density and well-known nutrition problems of these regions. In the lowland rice and upland intensive mixed systems of East Asia, the number of stunted children is about half of the South Asian systems mentioned previously, with 13 and 15 million stunted children respectively. In sub-Saharan Africa, the maize mixed and agro-pastoral millet sorghum systems have about six million stunted children each, half again as much as the East Asia systems mentioned above. Another seven farming systems across five world regions have between one and four million stunted children. The remaining five farming systems regions - two in the Middle East and North Africa regions and three in the Eastern Europe and Central Asia regions - have less than one million stunted children, mostly reflecting the lower overall populations of these regions.

\section{Where do DCL crops coincide?}

The DCL crops present a number of opportunities for bringing multiple technology options among different crops to the same geographic area (Figure 4). The map shows several core areas 


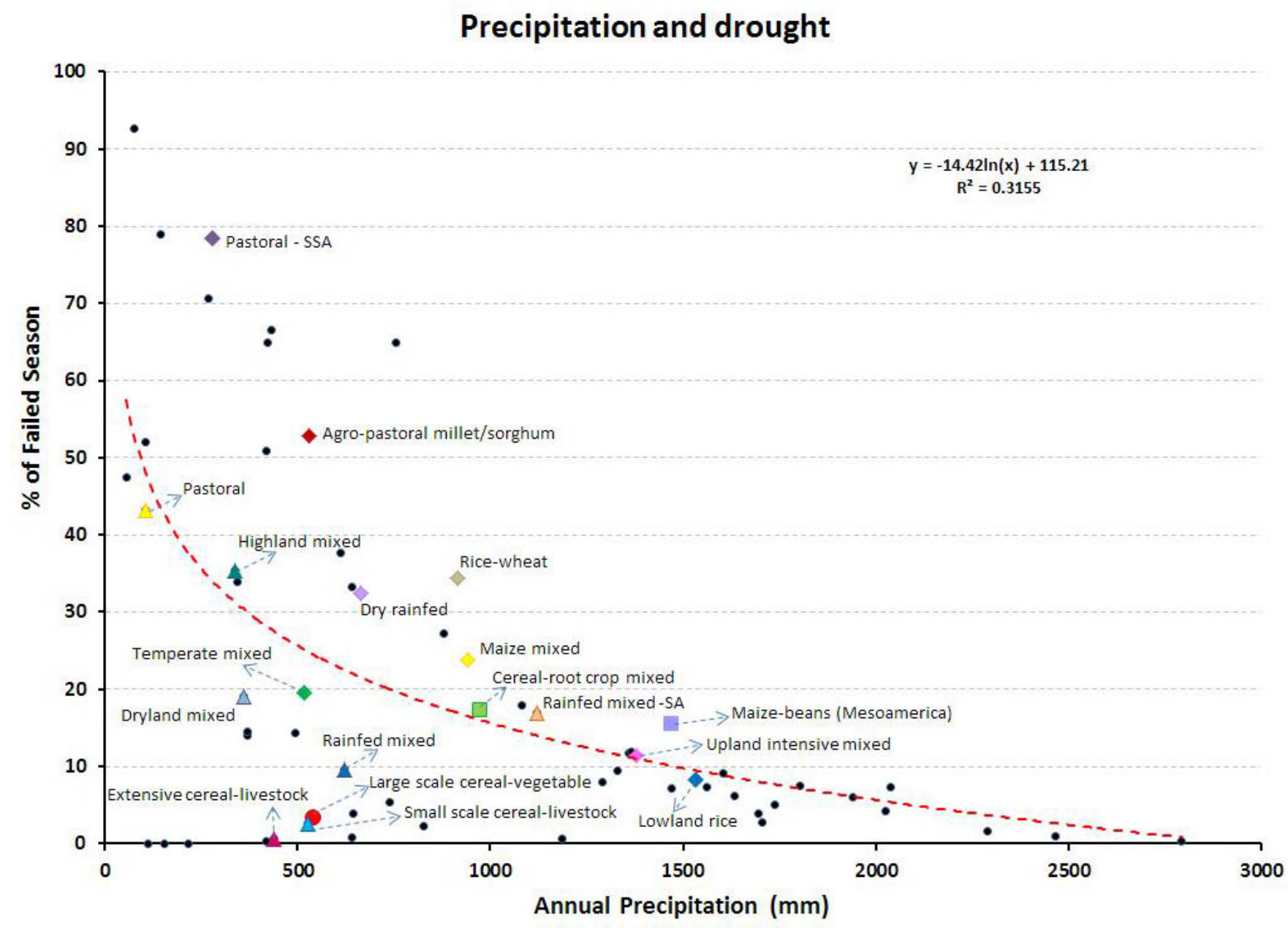

Figure 2. Average annual rainfall and average drought probability in 63 farming systems. Priority dryland cereal and legume farming systems are labeled.

where three to five or more DCL crops are grown together. These core areas include (1) a large area spanning the Sahel region of West Africa, (2) a discontinuous cluster of areas in East Africa, (3) a large part of South Asia extending from India north to Pakistan and then east to Bangladesh and Myanmar, and (4) a large swath of area in the Middle East extending from Iran to Turkey. But there are also concentrations of multiple crops in Mexico and Central America, China and other regions. Figure 5 shows some of the crop combinations with the largest area. In the Sahel region, a huge area where groundnut, pearl millet and sorghum are grown together is found. The eastern part of this region contains systems that include these crops plus common bean, while the Western part of the region includes the same crops and much more cowpea cultivation. In the Middle East, the combination of barley, chickpea, lentil and faba bean, make up large cultivated areas within the region.

\section{Discussion and Conclusions}

This study identified 18 farming systems globally that are important for dryland cereals and grain legumes agri-food systems. The most important of these systems, in terms of area and population, are found in South Asia and sub-Saharan Africa. The results discussed above suggests that these two regions deserve primary focus based on their relatively large cultivated area of DCL crops, large populations and high poverty. The farming systems in Latin America, the Middle East and North Africa, Central Asia and East Asia are also important. Research in any one region can have managed spillover effects in the others because the crops and biophysical conditions are similar across these regions. Interestingly, many DCL cereals and legumes show wide adaptability and have persisted in areas of moderate rainfall, such as the maize mixed farming system, and even in irrigated farming systems such as lowland rice.

A focus on the 18 farming systems identified in this study in no way excludes any areas of the globe as areas where DCL should conduct and target research and development. It simply narrows down the DCL focus area to areas with substantial production of DCL commodities, with drylands and with substantial poverty and development problems.

This result can be compared against two existing maps, both of which can be viewed on the website of the DCL Atlas. One map shows dryland ecologies and another shows the countries prioritized 
Table 6. The percentage area of each of the 18 priority farming system with soil constraints.

\begin{tabular}{|c|c|c|c|c|c|c|c|}
\hline $\begin{array}{l}\text { FARMING } \\
\text { SYSTEMS }\end{array}$ & REGION & $\begin{array}{l}\text { Acid Soil } \\
\text { constraints } \\
\text { (MEAN \% } \\
\text { of farming } \\
\text { system) }\end{array}$ & $\begin{array}{c}\text { Soil > } 3 \\
\text { months } \\
\text { dry } \\
\text { season } \\
\text { (MEAN \% } \\
\text { of farming } \\
\text { system) }\end{array}$ & $\begin{array}{l}\text { Soil subject to } \\
\text { waterlogging } \\
\text { (MEAN \% } \\
\text { of farming } \\
\text { system) }\end{array}$ & $\begin{array}{c}\text { Soil } \\
\text { with low } \\
\text { moisture } \\
\text { holding } \\
\text { capacity } \\
\text { (MEAN \% } \\
\text { of farming } \\
\text { system) }\end{array}$ & $\begin{array}{l}\text { Soil with } \\
\text { Low nutrient } \\
\text { availability } \\
\text { (MEAN \% } \\
\text { of farming } \\
\text { system) }\end{array}$ & $\begin{array}{c}\text { Soil with } \\
\text { Salinity } \\
\text { constraints } \\
\text { (MEAN \% } \\
\text { of farming } \\
\text { system) }\end{array}$ \\
\hline $\begin{array}{l}\text { Cereal-root crop } \\
\text { mixed }\end{array}$ & SSA & 37 & 1 & 14 & 22 & 19 & 1 \\
\hline Maize mixed & SSA & 27 & 4 & 7 & 14 & 35 & 1 \\
\hline $\begin{array}{l}\text { Agro-pastoral } \\
\text { millet/sorghum }\end{array}$ & SSA & 15 & 4 & 8 & 38 & 7 & 3 \\
\hline Pastoral & SSA & 5 & 20 & 4 & 30 & 2 & 6 \\
\hline Rice-wheat & SA & 19 & 21 & 7 & 5 & 4 & 23 \\
\hline Rainfed mixed & SA & 39 & 2 & 3 & 12 & 10 & 2 \\
\hline Dry rainfed & SA & 14 & 0 & 2 & 1 & 1 & 2 \\
\hline Highland mixed & MENA & 2 & 36 & 2 & 2 & 0 & 5 \\
\hline Rainfed mixed & MENA & 25 & 13 & 3 & 3 & 0 & 2 \\
\hline Dryland mixed & MENA & 7 & 38 & 1 & 5 & 0 & 5 \\
\hline Pastoral & MENA & 1 & 42 & 1 & 10 & 0 & 8 \\
\hline $\begin{array}{l}\text { Maize-beans } \\
\text { (Mesoamerica) }\end{array}$ & LAC & 30 & 1 & 3 & 3 & 14 & 0 \\
\hline $\begin{array}{l}\text { Large scale cereal- } \\
\text { vegetable }\end{array}$ & EECA & 17 & 5 & 11 & 6 & 0 & 5 \\
\hline $\begin{array}{l}\text { Small scale cereal- } \\
\text { livestock }\end{array}$ & EECA & 9 & 31 & 2 & 1 & 1 & 2 \\
\hline $\begin{array}{l}\text { Extensive cereal- } \\
\text { livestock }\end{array}$ & EECA & 11 & 2 & 15 & 6 & 0 & 1 \\
\hline Lowland rice & EAP & 22 & 0 & 35 & 5 & 30 & 2 \\
\hline $\begin{array}{l}\text { Upland intensive } \\
\text { mixed }\end{array}$ & EAP & 23 & 0 & 10 & 1 & 35 & 1 \\
\hline Temperate mixed & EAP & 10 & 1 & 35 & 2 & 0 & 18 \\
\hline
\end{tabular}

by the DCL research program (DCL, 2015). The dryland ecologies map is solely based on dryness, as indicated by temperature, precipitation and evapotranspiration. Effectively, the map includes large areas where there are very few people and almost no cultivated land. The 18 farming systems identified in this research fall within the dryland ecologies map. Two partial exceptions to this pattern are the maize-beans system in Mesoamerica and the rainfed mixed system in India, where the boundaries of the farming system extend beyond the dryland ecology boundaries.

DCL's target countries map - based on national-level data - was developed using a combination of factors, namely, target crop area, agricultural population, population under poverty, prevalence of child malnutrition, and to the extent that data was available, land degradation based on the satellite-derived Normalized Difference Vegetation Index (NDVI; Pettorelli et al., 2005). The emphasis was on countries in dryland ecologies. In an effort to prioritize the large number of countries (51+), the focus was defined to be on sub-Saharan Africa and South Asia, where the area under the combined DCL was the highest among an assembled list of LowIncome Food-Deficit Countries (Pingali \& Stringer, 2003). The target countries map also agrees well with the map of 18 farming systems. However, one drawback of the target countries approach is that it cannot distinguish between data representing the crop distribution and agroecology of DCL crops on the one hand, and country level data that was used for priority setting on the other. The results of this study overcome that obstacle by combining farming systems and countries, and by taking a more detailed spatial approach at subnational pixel level, as opposed to country level.

The results of this study can also be compared to a previous study that used the same approach, but with 23 crops, including the major staples rice, wheat, cassava and maize, among others 


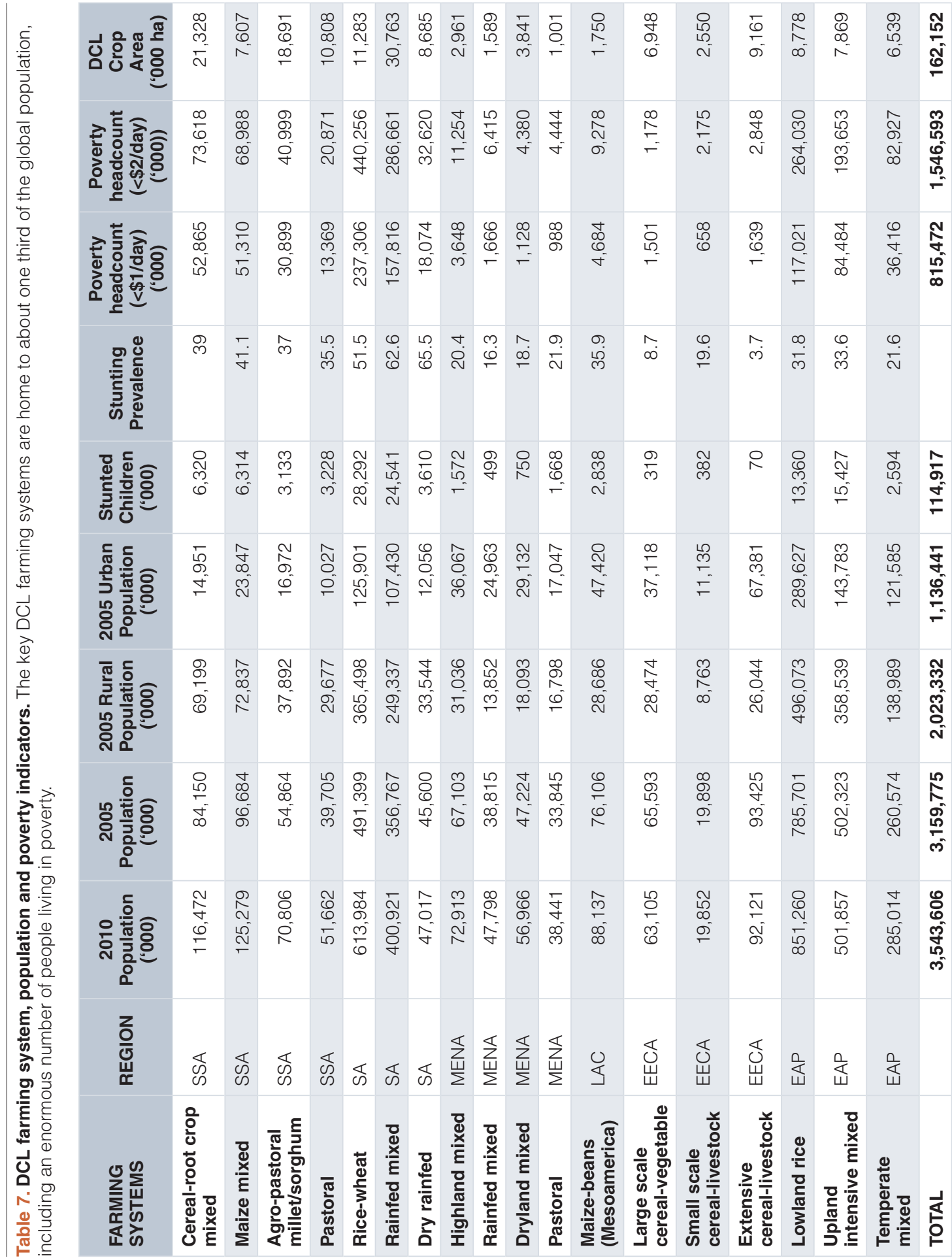




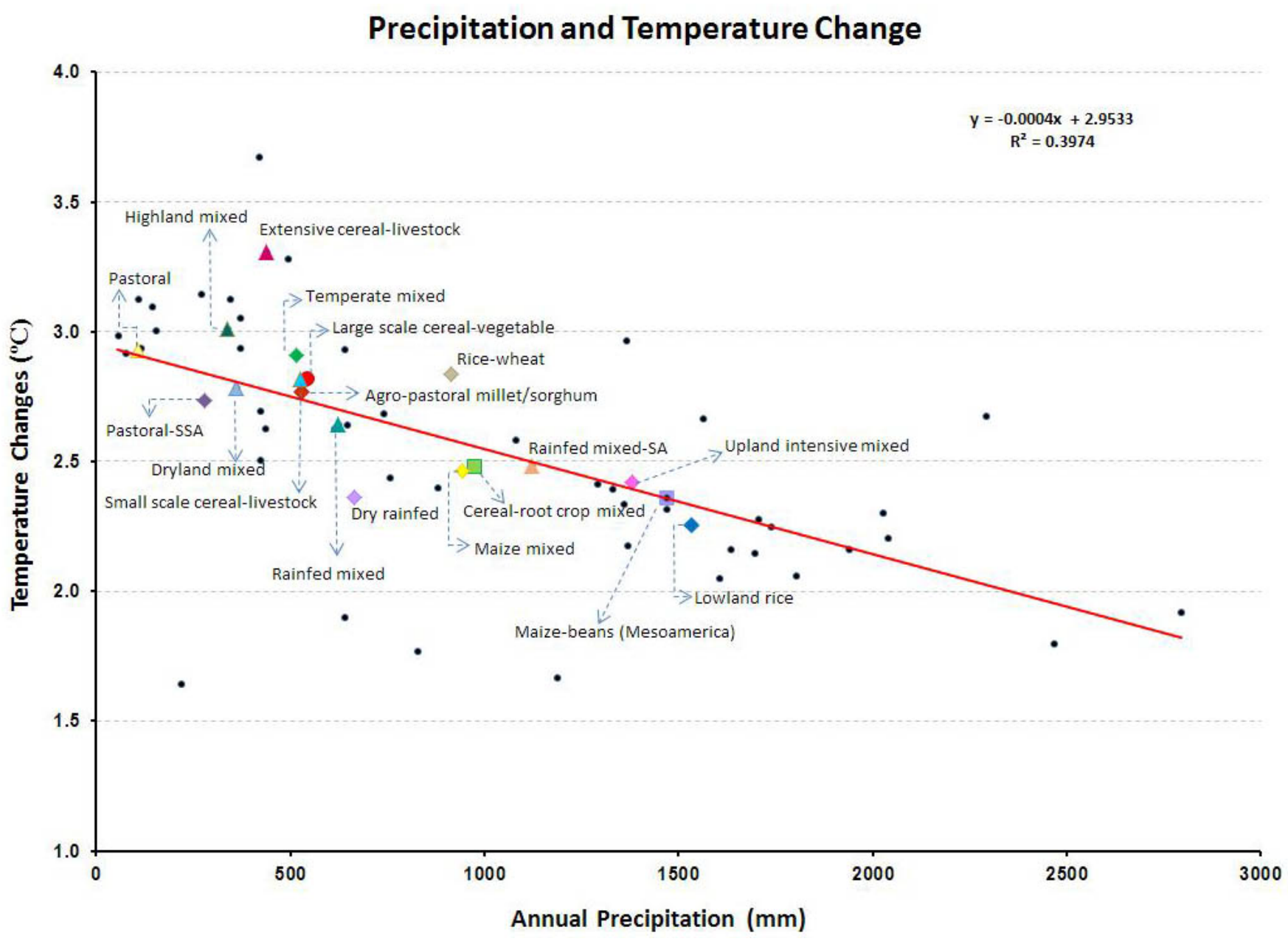

Figure 3. Average annual rainfall and average temperature change projected between the current temperature and 2050 temperature. Priority dryland cereal and legume farming systems are labeled.

(Hyman et al., 2008). That study focused on developing-country agriculture and prioritized 15 farming systems, with an emphasis on regions with large cultivated crop areas and large numbers of people. Seven of this study's farming systems were not included in the previous study - pastoral, dry rainfed (SA), highland mixed (MENA), dryland mixed, large-scale cereal vegetable, small-scale cereal livestock and extensive cereal-livestock. These seven systems are mostly focused on DCL crops, have generally lower populations and cultivated areas, have a greater tendency towards mixed livestock and cereal production and are found in areas with lower rainfall. Five of the 15 systems in the previous study do not appear in this study on DCL. Two of these systems are lowland and very wet - rice in South Asia and root crop in sub-Saharan Africa. The other three systems in the previous study but not found in this one are highland systems in South Asia, sub-Saharan Africa and East Asia. The eight systems found in both studies show the importance of DCL crops to the global agricultural research and development effort. Six of the most important farming systems globally from the previous study (Hyman et al., 2008) are also systems important for DCL. They are rice-wheat and rainfed mixed in South Asia, cereal-root crop and maize mixed in sub-Saharan Africa and upland intensive mixed and lowland rice in East Asia. While the latter two systems have relatively small proportions of DCL crops, the absolute areas and benefiting populations are large in densely populated Southeast and East Asia.

Dryland cereal and legume crop distribution data show that South Asia and sub-Saharan Africa are the most important regions for crop improvement and adapted crop management practices. However, the proportional area of many DCL crops is often relatively low in regions where rice, wheat and maize are important staples. Nevertheless, the DCL crops are important in these regions for several reasons. Grain legumes in particular may be important as a rotation crop to support soil nitrogen fixation. Because livestock are important in many of the 18 farming system regions prioritized in this research, taking advantage of crop-livestock system synergies is an opportunity that should be explored, especially in relation to fodder. Also, the benefits of pasture and long term crop rotations in relation to soil improvement and reduction of plant disease can be considerable. The substantial ranges between yields 


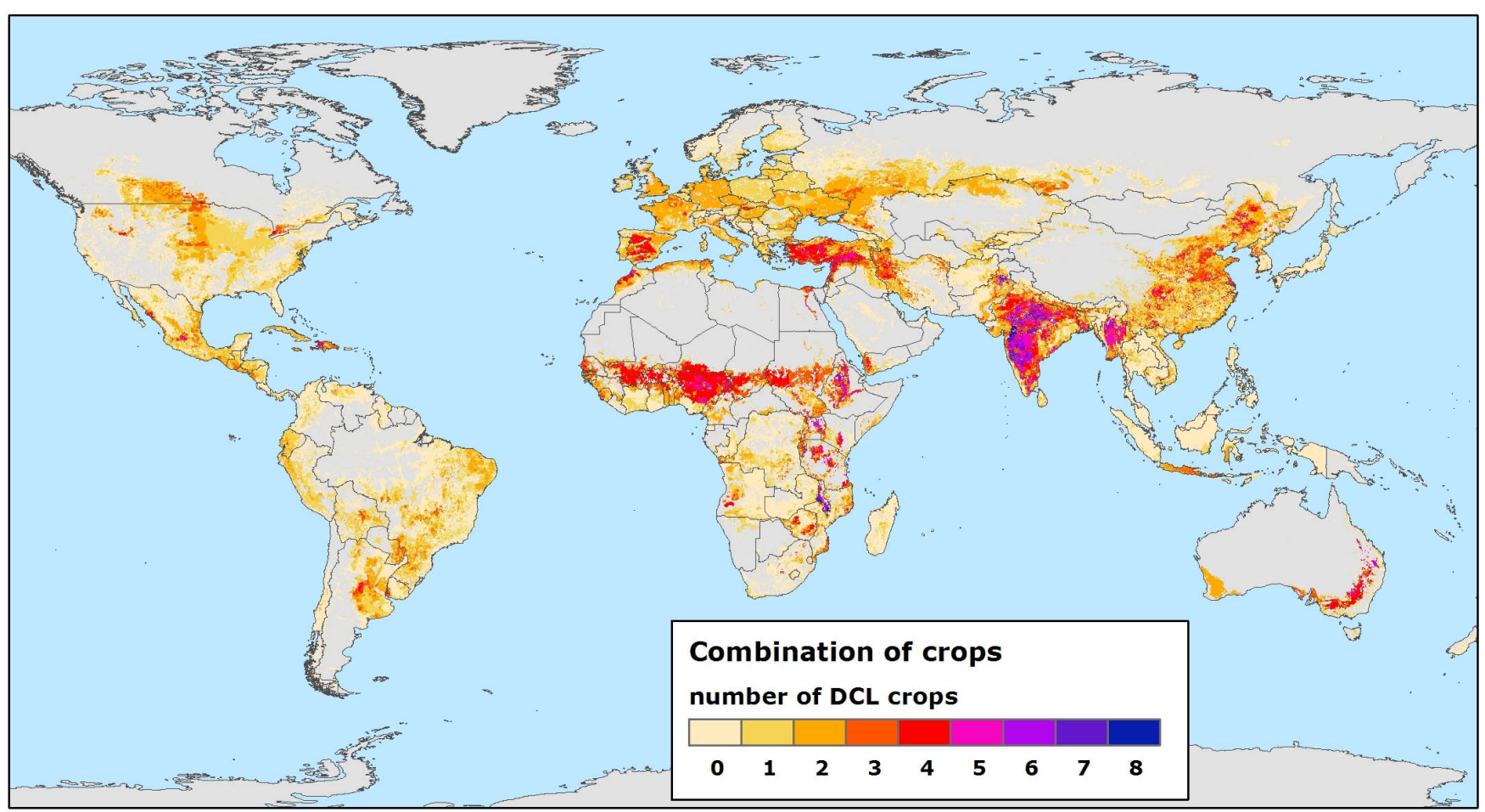

Figure 4. The DCL crops present a number of opportunities for bringing multiple technology options among different crops to the same geographic area. The map shows several core areas where 3 to 5 or more DCL crops are grown together.

in different regions of the world suggest considerable scope for closing yield gaps. These differences suggest substantial opportunities for increasing sub-Saharan Africa and South Asian yields.

Abiotic constraints are significant obstacles to improving DCL production. Previous research showed that farmers in these DCL priority farming systems face potential drought conditions that have a much higher risk compared to most other farming systems (Hyman et al., 2008). Rising temperatures in DCL farming systems will place a growing demand on farmers to cultivate heat tolerant crops, and to develop practices to protect these crops. Farming systems on the edge of the tropics or in the subtropics, as one moves away from the equator, are more likely to face rising temperatures with climate change. The combined effects of drought and heat in these farming systems pose a significant challenge. The areas in the 18 priority farming systems show considerable soil limitations. One of the most important is infertility, as indicated by soil acidity and low nutrient reserves - for which legume crops are valuable. Other important soil limitations are related to water. Long dry seasons limit the water availability in the soil, which is compounded in coarse-textured soils with low water holding capacity, for which modern crop management practices are applicable. The dryness of these systems also make them susceptible to salinity, another important soil constraint in the DCL priority systems.

Socioeconomic conditions in the DCL priority systems identified in this study indicate high levels of population and high poverty. There are both large rural and urban populations, suggesting potential positive supply and demand dynamics, especially so in sub-Saharan Africa and South Asia. These conditions suggest opportunities for developing market oriented production. Clearly much of the DCL crop production will continue to be derived from semi-subsistence agriculture. The high levels of malnutrition as indicated by childhood stunting, especially in South Asia and sub-Saharan Africa, can be addressed in part by nutritious DCL crops, which are often important sources of protein and micronutrients. Biofortification of DCL crops could be an important consideration in these areas. Clearly, the high rural and urban population found in, and depending on, DCL farming system regions suggest the importance of these systems for research and development aimed at improving agriculture and livelihoods.

The areas where DCL crops occur together present opportunities for improving the efficiency of research and development because fixed costs of research activities can be shared by different crop commodity programs. Testing the performance of crop varieties is typically carried out by national agricultural research institutes in collaboration with CGIAR centers. An integrated program to develop joint research could take advantage of different CGIAR centers or commodity programs carrying out research activities at common experiment stations of a national agricultural research institute. Two regions stand out where DCL crops occur together (Figure 5). An initiative to work on multiple crops in the same sites may be attractive for (1) millet, sorghum, groundnut and cowpea crops in the Sahel region, and for (2) barley, chickpea, lentil and faba bean in the Middle East. 


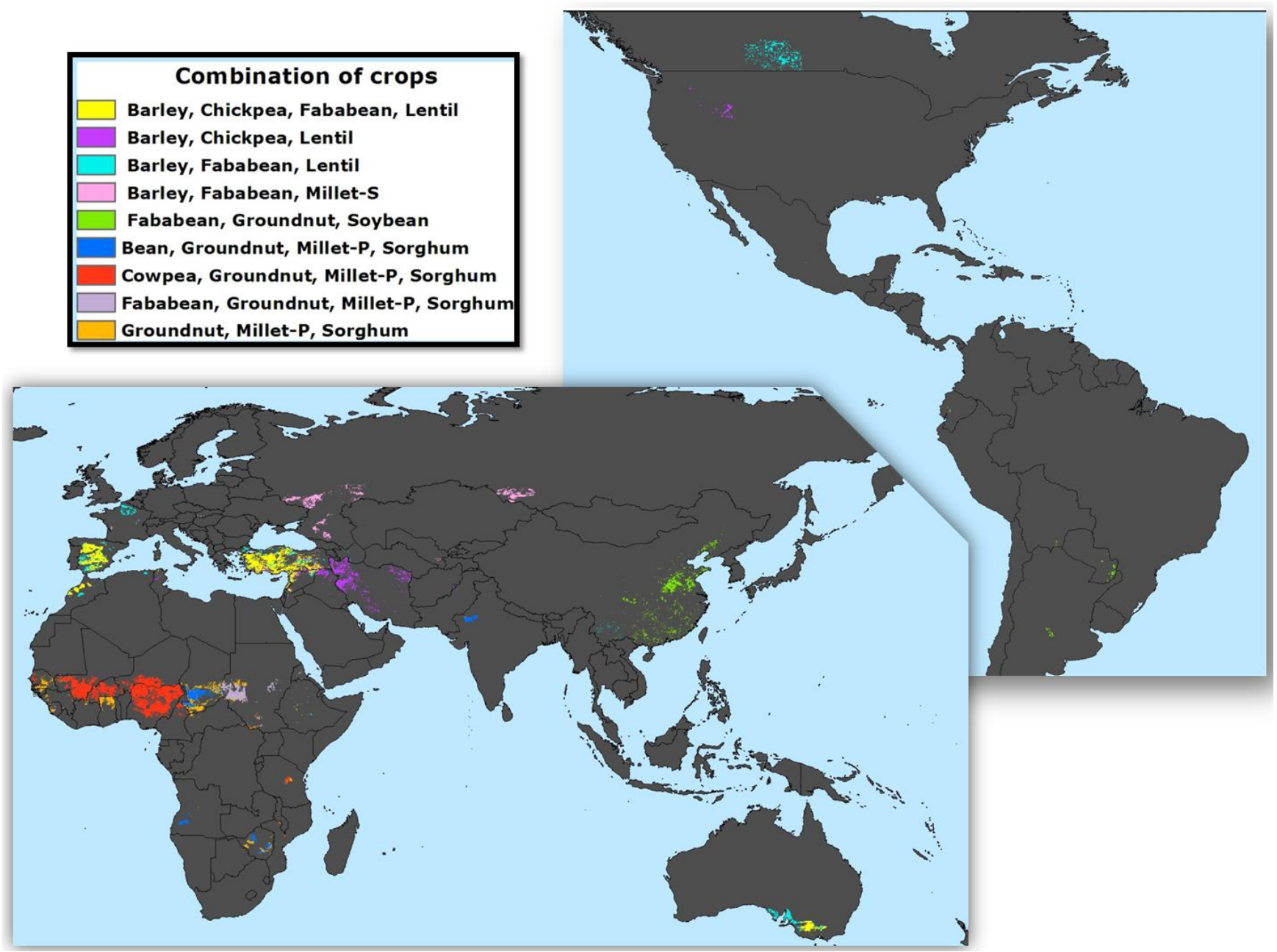

Figure 5. Crop combinations with the largest area.

This study points out several areas for further agricultural research to improve productivity of dryland cereals and legumes. First, an effort can be made to update this analysis using more recent data with higher temporal resolution. Using recent data is particularly important for crop distribution and socioeconomic data. This type of analysis will surely benefit from higher spatial resolution of geospatial data in the future, a trend increasingly common with improving capacities to collect, store and process geographic information. Perhaps the most substantial gap in this study has been the lack of information on biotic constraints to crop production. Pests and diseases are often the most important threats facing farmers. But to date there are few consistent and standardized geographic assessments of the major pests and disease threats to crops, notwithstanding the progress made on wheat rust prevalence (Singh et al., 2008). Overcoming this obstacle would require a systematic effort to collect information on the occurrence of biotic constraints. A recent paper showed the potential of improving our knowledge of the geographic dimensions of agricultural biodiversity (Castañeda et al., 2016). Interestingly, that research showed that the dryland systems area of the Middle East and North Africa is a priority for collecting wild relatives of food crops. Our research suggested the importance of temperature and precipitation under climate change for the future of DCL crops. Research is needed on understanding the sensitivity of each crop to increases in temperature and to the duration of drought conditions. Research is also needed on understanding genotype by environment interactions for the DCL crops. Other staple crops such as maize, wheat and rice have a better track record in these types of studies, suggesting a higher potential return on investment for this type of research on DCL crops in the future. In relation to comprehensive analyses which position DCL crops in the full farming systems in the two priority regions for DCL crops, a new edited volume will be valuable, a forthcoming book titled Farming Systems and Food Security in Africa: Priorities for Science and Policy Under Global Change, edited by John Dixon, Dennis Garrity, Jean-Marc Boffa, Tim Williams, Tilahun Amede with Christopher Auricht, Rosemary Lott and George Mburathi. A similar comprehensive analysis is recommended for South Asia. 


\section{Declarations}

Data availability

This research initiative developed two general types of data digital spatial data of the world related to DCL crops and tabular data that summarizes the geographic information by farming system and country. All the spatial data used in the analysis can be accessed from the DCL Atlas at http://www.eatlasdcl.cgiar.org/. This online atlas includes data on the distribution of the 12 DCL crops, maps of predicted suitability of each crop, maps of abiotic constraints to crop production, maps of the biodiversity of relatives of each crop species, maps of socioeconomic conditions important for understanding the environment where these crops are grown and reference maps for putting all this information in the context.

Tabular data summarizing geographic information by farming system and country can be found in two dataset resources on the Dataverse repository:

Harvard Dataverse: Replication Data for: Priority regions for research on dryland cereals and legumes, 10.7910/DVN/EDMXSK (Barona et al., 2016a).

Harvard Dataverse: Characterization data on crops, production systems, abiotic constraints, population and poverty for farming system regions of the world, 10.7910/DVN/PLJ4SC (Barona et al., 2016b).

\section{Author contributions}

GH, EB and SB conceived the study. GH, EB, SB and SS designed the research. EB, CB, SC, HE, EG and OR prepared the datasets for processing and analysis. GH and JD wrote the manuscript. All authors interpreted and discussed the results and commented on the manuscript.

\section{Competing interests}

This research was commissioned by the CGIAR, a consortium of international research centers where all but one of the authors is employed. Future funding of research programs on dryland cereals and legumes could be influenced by the results and information found in this paper, which could impact on funds received by individual CGIAR centers. The authors declare no direct competing interest. All organizations for which the authors are employed are nonprofit organizations dedicated to developing global public goods.

\section{Grant information}

This research was commissioned by the CGIAR Research Programs on Grain Legumes (http://grainlegumes.cgiar.org/) and on Dryland Cereals (http://drylandcereals.cgiar.org/). The CGIAR Fund (http://www.cgiar.org/who-we-are/cgiar-fund/) provided financial support for the study to the authors from four Consultative Group on International Agricultural Research (CGIAR) centers - CIAT, ICARDA, ICRISAT and IITA.

The funders had no role in study design, data collection and analysis, decision to publish, or preparation of the manuscript.

\section{Acknowledgements}

We thank Liang You of the International Food Policy Research Institute (IFPRI) and Nora Castañeda-Álvarez of CIAT and the Crop Wild Relatives project for data on crop distributions and crop biodiversity, respectively, and for advice on the use of this data. We thank the CGIAR Research Program on Dryland Cereals and Legumes Agri-Food Systems (DCL), the International Center for Agricultural Research in the Dry Areas (ICARDA) and the International Center for Tropical Agriculture (CIAT) for providing in-kind support to this research.
Barona E, Guevara E, Hyman G: Replication Data for: Priority regions for research on dryland cereals and legumes. [online] Harvard Dataverse, V1 [UNF: 6:IoJm7wy0VRiSBz6QuGnfbA==]. 2016a. Publisher Full Text

Barona E, Guevara E, Hyman G: Characterization data on crops, production systems, abiotic constraints, population and poverty for farming system regions of the world. [online] Harvard Dataverse, V1. 2016 b. Publisher Full Text

Castañeda-Álvarez NP, Khoury CK, Achicanoy HA, et al:: Global conservation priorities for crop wild relatives. Nat Plants. 2016; 2: 16022.

Publisher Full Text

CIESIN (Center for International Earth Science Information Network), FAO (Food and Agriculture Programme), CIAT (Centro Internacional de Agricultura Tropical): Gridded Population of the World, Version 3 (GPWv3): Population Count Grid. [online] Columbia University, United Nations. Palisades, NY: NASA Socioeconomic Data and Applications Center (SEDAC). 2005.

Publisher Full Text

CIESIN (Center for International Earth Science Information Network): Poverty Mapping Project: Global Subnational Prevalence of Child Malnutrition. Columbia University, Palisades NY, NASA Socioeconomic Data and Application Center (SEDAC). 2005

Reference Source

CIESIN (Center for International Earth Science Information Network): Gridded Population of the World, Version 4 (GPWv4): Preliminary Release 2 (2010).

[online] Columbia University Palisades, NY, 2014.

Reference Source
DCL (Dryland Cereals and Legumes): Dryland Cereals and Legumes Agri-food. Systems: Pre-proposal. 2015.

Reference Source

DESA (Department of Economic and Social Affairs): Rethinking Poverty: Report on the World Social Situation 2010. New York. 2009.

Reference Source

de Onis M, Blössner M, Borghi E: Prevalence and trends of stunting among pre-school children, 1990-2020. Public Health Nutr. 2012; 15(1): 142-148. PubMed Abstract | Publisher Full Text

Dixon J, Gulliver A, Gibbon D: Farming Systems and Poverty: Improving Farmers' Livelihoods in a Changing World. FAO and World Bank, Rome and Washington DC, USA, 2001.

Reference Source

Fischer G: Length of growing period data. Data not available for distribution. 2009.

Reference Source

FAO (Food and Agriculture Organization): Prevalence of stunting among children under five, by lowest available subnational Administrative unit, varying years (FGGD-Digital Atlas). Rome, 2007.

Reference Source

Hartman GL, West ED, Herman TK. Crops that feed the World 2 Soybeanworldwide production, use, and constraints caused by pathogens and pests. Food Sec. 2011; 3(1): 5-17.

Publisher Full Text

Hijmans RJ, Cameron SE, Parra JL, et al:: Very high resolution interpolated 
climate surfaces for global land areas. Int J Climatol. 2005; 25(15): 1965-1978. Publisher Full Text

Hyman G, Fujisaka S, Jones $P$, et al.: Strategic approaches to targeting technology generation: Assessing the coincidence of poverty and drought-prone crop production. Agr Syst. 2008; 98(1): 50-61.

Publisher Full Text

Hyman G, Hodson D, Jones P: Spatial analysis to support geographic targeting of genotypes to environments. Front Physiol. 2013; 4: 40.

PubMed Abstract | Publisher Full Text | Free Full Text

Hyman G, Fujisaka S, Jones P, et al:: Replication data for: Strategic approaches to targeting technology generation: Assessing the coincidence of poverty and drought-prone crop production. [online] Harvard Dataverse, V1. 2015. Publisher Full Text

Jones PG, Thornton PK: MarkSim: Software to generate daily weather data for Latin America and Africa. Agron J. 2000; 92(3): 445-453.

Publisher Full Text

Jones PG, Thornton PK, Diaz W, et al:: MarkSim, Version 1. A computer tool that generates simulated weather data for crop modelling and risk assessment. Centro Internacional de Agricultura tropical (CIAT) CD-ROM series. Cali, Colombia: CIAT. CD-ROM + Guide. 2002; 87.

Reference Source

Newton AC, Flavell AJ, George TS, et al.: Crops that feed the world 4. Barley: a resilient crop? Strengths and weaknesses in the context of food security. Food Secur. 2011; 3(2): 141-178.

Publisher Full Text

Pettorelli N, Vik JO, Mysterud A, et al:: Using the satellite-derived NDVI to assess ecological responses to environmental change. Trends Ecol Evol. 2005; 20(9): 503-510.

PubMed Abstract | Publisher Full Text

Pingali P, Stringer R: Food Security and Agriculture in the Low Income, Food-Deficit countries: 10 years after the Uruguay Round. 2003; (No. 03-18) Reference Source
Ramirez J, Jarvis A: High resolution statistically downscaled future climate surfaces. International Center for Tropical Agriculture (CIAT); CGIAR Research Program on Climate Change, Agriculture and Food Security (CCAFS), Cali-Colombia 2008.

Reference Source

Robinson TP, Wint GR, Conchedda G, et al:: Mapping the global distribution of livestock. PLoS One. 2014; 9(5): e96084

PubMed Abstract | Publisher Full Text | Free Full Text

Sanchez PA, Palm CA, Buol SW: Fertility Capability Soil Classification: a tool to help assess soil quality in the tropics. Geoderma. 2003; 114(3-4):

157-185.

Publisher Full Text

Singh RP, Hodson DP, Huerta-Espino J, et al.: Will stem rust destroy the world's wheat crop? Adv Agron. 2008; 98: 271-309.

Publisher Full Text

Smith RM: Comparing traditional methods for selecting class intervals on choropleth maps. Prof Geogr. 1986; 38(1): 62-67.

Publisher Full Text

You L, Wood S: An entropy approach to spatial disaggregation of agricultural production. Agric Syst. 2006; 90(1-3): 329-347.

Publisher Full Text

You L, Wood S, Wood-Sichra U, et al:: Generating global crop distribution maps: From census to grid. Agric Syst. 2014a; 127: 53-60.

Publisher Full Text

You L, Wood-Sichra U, Fritz S, et al.: Spatial Production Allocation Model (SPAM) 2005 v2.0. 2014b.

Reference Source

Zomer RJ, Trabucco A, Bossio DA, et al:: Climate change mitigation: A

spatial analysis of global land suitability for clean development mechanism afforestation and reforestation. Agr Ecosyst Environ. 2008; 126(1-2):

67-80.

Publisher Full Text 


\section{Open Peer Review}

\section{Current Peer Review Status:}

\section{Version 1}

Reviewer Report 06 June 2016

https://doi.org/10.5256/f1000research.9316.r14209

(C) 2016 You L. This is an open access peer review report distributed under the terms of the Creative Commons Attribution License, which permits unrestricted use, distribution, and reproduction in any medium, provided the original work is properly cited.

\section{Liangzhi You \\ International Food Policy Research Institute, Washington, DC, USA}

Efficient allocation of limited research resources is a central policy issue for international development agencies, developing-country governments, and their agricultural research institutes. Priority setting in agricultural research systems is a principal means of ensuring the effectiveness of investment in agricultural research. The new CGIAR has emphasize more on research impact on development. As part of the CGIAR research program on dryland cereal and legumes, this paper developed an open access dataset and information resource that provides the basis for future analysis of the geographic dimensions of dryland cereals and legumes.

The foremost important contribution of this paper is to integrate multiple global spatial databases on cropping system, livestock and biophysical conditions for setting the priority. These newly available datasets allows the priority setting at crop-type level in a truly spatially explicit manner. The use of geographic information system (GIS) and spatial analysis captured the effects of agroecological variation and huge spatial heterogeneity of farming system, the response of agricultural technologies, the technological spillovers.

The next strength of the paper is its open access. The paper itself is open access. The datasets used in the paper is also openly available. Interested users could download these datasets and repeat/improved the analysis undertook in the paper.

The weakness is the methodology section. While the paper spent quite some effort/sections on data sources, summary of results, the methodology is quite short and not clear. Admittedly the readers are referred to the well-known farming system framework by Dixon et al., and the authors' previous work. The methodology should be updated and improved with the new datasets and tools. A brief summary is warranted. Technical details on how to deal with spatial fragmentation (e.g due to many different data layers) would be helpful for those who would like to learn and repeat the analysis of this paper.

Competing Interests: No competing interests were disclosed. 


\section{I confirm that I have read this submission and believe that I have an appropriate level of expertise to confirm that it is of an acceptable scientific standard.}

Reviewer Report 25 May 2016

https://doi.org/10.5256/f1000research.9316.r13828

(C) 2016 Ehlers J. This is an open access peer review report distributed under the terms of the Creative Commons Attribution License, which permits unrestricted use, distribution, and reproduction in any medium, provided the original work is properly cited.

\section{Jeffrey D. Ehlers}

Bill and Melinda Gates Foundation, Seattle, WA, USA

Positives:

Using a basic farming system characterization schema developed some 15 years prior, this paper selects 18 of these where key dryland cereals and legume crops (DCL crops) are important, and refines their boundaries using new data and GIS resources. This work then provides a needed update to the earlier 2001 work. Each of these cropping system units is then characterized with DCL crop information (area grown, productivity, proportion of area, present and future drought severity, as well as socio-economic data such as population and poverty, as well as with cattle population data, to create an information rich view of these systems. This work therefore helps in discovering appropriate and high leverage investment opportunities that support economic development. Another value of the article is that it serves to publicize an open access dataset and information resources that can be used in future analysis of DCL systems.

A valuable contribution of this work is the integration of datasets/information across the DCL crop, agro-ecological and socio-economic dimensions, especially at sub-national level. At the same time there is little doubt the data sets used in the analysis were of highly variable quality. It seems like it would be good to face this head-on and include more discussion around data quality issues and how much confidence the reader should put in the analysis given that some of the data likely to be of low to moderate quality. How are conclusions affected when integrating datasets on one topic that are of high quality with another for another parameter that are of poor quality?

The authors usefully point out some important research areas that need attention in the DCL crops to make the current maps more actionable. These include things like relative response to higher temperature, genotype by environment interactions but also that 'one of the most important shortcomings in this type of analysis has been the lack of data with which to produce a biotic constraints map layer as these types of constraints can be key drivers of crop distribution.

Competing Interests: No competing interests were disclosed.

I confirm that I have read this submission and believe that I have an appropriate level of expertise to confirm that it is of an acceptable scientific standard. 
The benefits of publishing with F1000Research:

- Your article is published within days, with no editorial bias

- You can publish traditional articles, null/negative results, case reports, data notes and more

- The peer review process is transparent and collaborative

- Your article is indexed in PubMed after passing peer review

- Dedicated customer support at every stage

For pre-submission enquiries, contact research@f1000.com 